\title{
Alternative Proteins in Brazil: Nomenclature for Plant Based \& Cultured Meat
}

\author{
Chris Bryant ${ }^{1}$ \& \\ Felipe Krelling ${ }^{2}$
}

\footnotetext{
${ }^{1}$ Department of Psychology, University of Bath, United Kingdom

${ }^{2}$ The Good Food Institute, Brazil
}
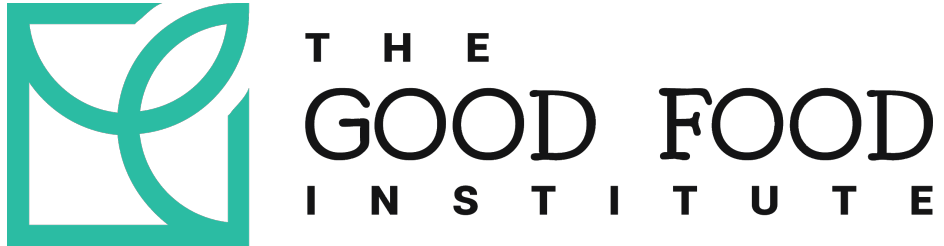


\section{Executive Summary}

Plant based and cultured meat are two important technologies with the potential to satisfy consumer demand for meat while avoiding the ethical, envrionmental, and public health problems with conventional meat production. In this study, we investigate consumer demand for these products in Brazil, one of the largest meat-producing and -consuming countries in the world. We present the results of two experiments on the nomenclature of plant-based meat $(\mathrm{N}=869)$ and cultured meat $(\mathrm{N}=983)$. We find overall high levels of acceptance for both alternatives: $76.5 \%$ would try and $65.6 \%$ would buy cultured meat, while $84.9 \%$ would try and $72.1 \%$ would buy plant-based meat. Experimental results suggest that the optimal names, all things considered, are carne cultivada (cultured meat) and carne feita de plantas or carne vegetal (plant based meat). We also find slightly differing consumer profiles for either product, with cultured meat being more appealing to men and plant based meat showing more appeal for women and those already following vegetarian diets. The key attitudes driving purchase intent for cultured meat include perceived healthiness and appeal, whereas for plant-based meat the key attitudes driving purchase intent include perceived tastiness. 


\section{Background}

Brazil is a country which is of central importance to the global meat industry. Although it is the sixth most populous country, Brazil is the second largest beef producer behind the USA, and is a close third in total beef consumption behind the USA and China (OECD-FAO, 2020). It is also home to the Amazon, a natural resource which is vital to countering climate change and is being decimated by animal agriculture and its feed systems (Brown, 2009; Pereira et al., 2020).

Interestingly, there is evidence that Brazilians tend to have greater concern for animal welfare than other nationalities (Anderson \& Tyler, 2018), and indeed researchers investigating alternative protein acceptance in Brazil have observed this. Valente et al. (2019) found that about half of their Brazilian sample said there were problems with the consumption of meat from animals, and the most commonly cited problem was animal suffering (though it should be noted that this sample skewed towards urban-dwelling women, a demographic with a higher than average expected concern for animal welfare (Bryant, 2019)).

A 2018 report by The Good Food Institute and Snapcart found that health was the most common motivation by far for both vegetarians (43\%) and meat-reducers (59\%) in Brazil. Recent reports highlighting the health advantages of plant-based meat compared to animal meat (Crimarco et al., 2020; Food Frontier, 2020) could provide evidence to persuade Brazilian consumers away from meat-heavy diets towards alternatives.

However, Gomez-Luciano et al. (2019) found that Brazilians were significantly more likely to view meat as nutritionally necessary compared to participants from the UK, Spain, and the Dominican Republic. This study also found that Brazil is less accepting of alternative proteins than Spain and the UK. In particular, Brazilians perceived plant-based meat as more expensive, less safe, less nutritious, and less tasty relative to other countries. They also perceived cultured meat as more expensive, less tasty, and less safe relative to other countries.

This study aimed to:

1. Establish the level of overall consumer acceptance for plant-based and cultured meat in Brazil.

2. Test the difference between different proposed names for plant-based and cultured meat in terms of consumer acceptance, descriptiveness, and ability to differentiate from other types of meat.

3. Identify particular demographic factors associated with plant-based and cultured meat acceptance in Brazil.

4. Identify which beliefs and attitudes predict purchase intent for plant-based and cultured meat in Brazil. 


\section{Methods}

\subsection{Process}

First, the research team identified potential names from a literature search as well as soliciting suggestions from various stakeholders connected to alternative proteins, including government representatives, investors, food companies, food scientists and food industry representatives. The compiled list of names were then given subjective ratings out of 5 by the research team for their likely consumer appeal, descriptiveness, and ability to differentiate them from other types of meat. This process identified three potential names for plant-based meat which met minimum standards for all of these factors and four for cultured meat (see Table 1).

Table 1. The different names for plant-based and cultured meat tested in the survey.

\begin{tabular}{|l|l|l|l|}
\hline \multicolumn{2}{|c|}{ Plant-Based meat } & \multicolumn{2}{c|}{ Cultured meat } \\
\hline \multicolumn{1}{|c|}{ Name used } & English translation & \multicolumn{1}{c|}{ Name used } & English translation \\
\hline $\begin{array}{l}\text { Carne feita de } \\
\text { plantas }\end{array}$ & Plant-based meat & Carne cultivada & $\begin{array}{l}\text { Cultured/cultivated } \\
\text { meat }\end{array}$ \\
\hline Carne vegetal & Vegetable meat & $\begin{array}{l}\text { Carne de base } \\
\text { celular }\end{array}$ & Cell based meat \\
\hline Carne vegana & Vegan meat & Carne limpa & Clean meat \\
\hline & & Carne sem abate & Slaughter free meat \\
\hline
\end{tabular}

Having established which names would be tested in the experiment, we constructed our survey instrument in Qualtrics. The survey component of this study was approved by the University of Bath Psychology Research Ethics Committee.

First, participants read some information about the study and gave their consent to take part. Participants were randomly allocated to see a version of the survey using one of the different names, but otherwise the surveys were identical. Participants read the following description of plant-based meat (translated from Portuguese), in which [PBM] was replaced with one of the tested names.

A recent discovery in food innovation allows us to produce meat in a different way. [PBM] is made entirely of plants and has no animal ingredients. It is made using vegetable ingredients, such as proteins, fats, and carbohydrates to mimic the structure of conventional meat. [PBM]

is produced in a clean factory, very similar to a brewery. The process does not involve the practice of raising and slaughtering animals. The final product is very similar in taste and 
texture compared to conventional meats. [PBM] offers significant benefits for human health, the environment, and animal welfare. Several companies have already launched [PBM] in retailers and restaurants. Such products are increasingly popular.

In the cultured meat survey, participants read the following description of cultured meat (translated from Portuguese) in which [CM] was replaced with one of the tested names.

A recent discovery in food innovation allows us to produce meat in a different way. [CM] is identical to the cell level with conventional meats. This meat grows directly from animal cells. [CM] is produced in a clean factory, very similar to a brewery. The process does not involve the practice of raising and slaughtering animals. The final product is identical in taste and texture compared to conventional meats. [CM] offers significant benefits for human health, the environment, and animal welfare. Several companies have already managed to produce [CM] that have been tested for flavor. Such products will be available on the market for 1-5 years.

Participants then indicated how familiar, if at all, they were with either product. Following this was an attention check question, which was used to identify automated responses or those not giving thoughtful answers.

Next, participants answered questions about whether they would try and buy cultured/plantbased meat, whether they would use them to replace conventional meat, and whether they would pay more for them. They then rated the products on 5-point scales on a variety of bipolar scales including 'dangerous - safe', 'expensive - affordable', and 'not tasty - tasty'. Following this, they gave their opinions of the name they read in terms of its descriptiveness and ability to differentiate each product from each other, as well as from conventional meat. Finally, participants answered some demographic questions, and were debriefed and thanked for their participation.

\subsection{Participants}

Participants were recruited through the research panel Positly, and were compensated for their time through Positly's partner organisation's CINT's incentives program. Their incentives can be paid as cash, online shopping discounts, or charitable donations, and are set for each survey to encourage long-term membership in the panel.

We aimed for sample sizes in line with those recommended by Cohen (1992) to detect a small effect at $p=.05$. For the plant-based meat survey, we attained a final sample of $n=869$ across three experimental conditions. For the cultured meat survey, we attained a final sample of $n=983$ across four experimental conditions. The demographics of both samples are shown in Figures 1 and 2. 
Figure 1: Age and gender distributions in the cultured meat survey $(n=983)$

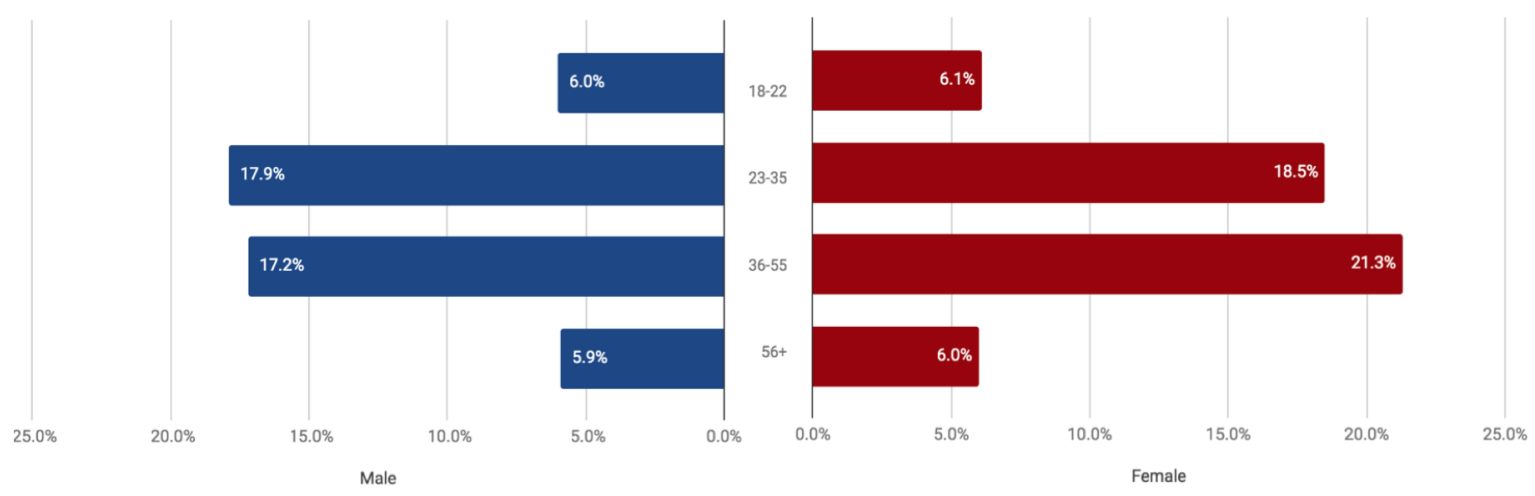

Figure 2: Age and gender distributions in the plant-based meat survey $(\mathrm{n}=869)$

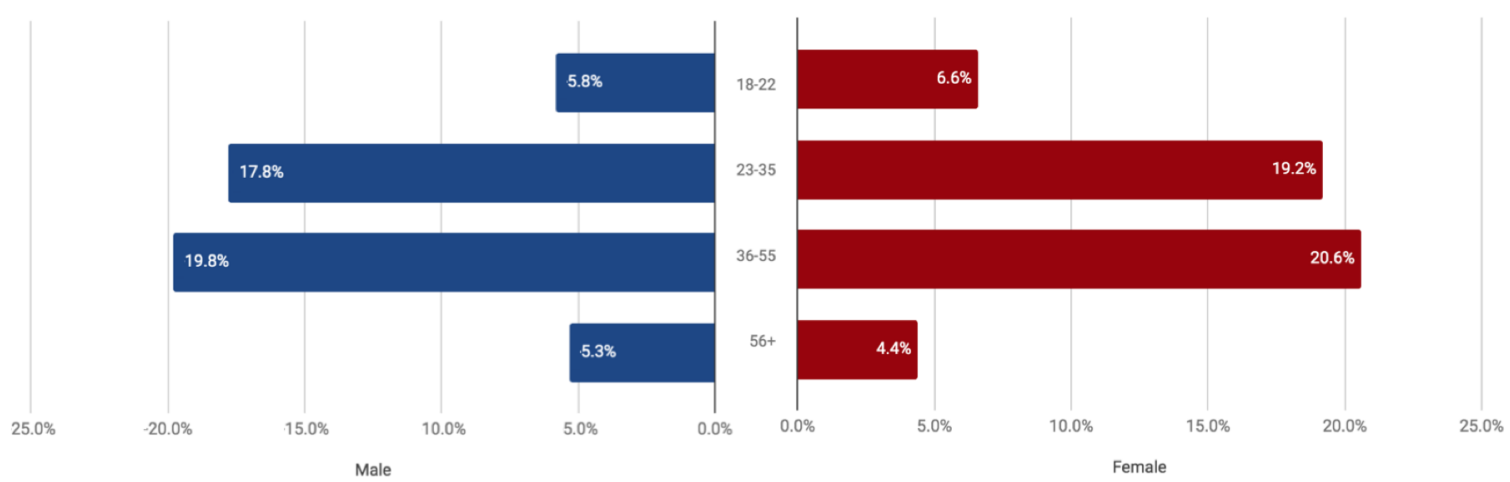

\subsection{Analysis}

We used a variety of statistical methods to answer our three research questions.

First, to establish the overall level of acceptance for plant-based and cultured meat, we simply reported descriptive statistics: the percentages of each sample who said that they would (and would not) try, buy, and pay more for plant-based and cultured meat. These figures are instructional in gauging the overall consumer appeal of each product in the country.

Second, to test relevant differences between different names for each product, we used oneway ANOVAs to compare mean scores of acceptance, descriptiveness, and ability to differentiate the product from other types of meat. Differences were considered significant where $p<.05$ in the omnibus ANOVA, and in these cases, we conducted post-hoc Tukey comparisons to show significant differences between specific pairs of names. 
Third, to identify demographic factors which were associated with more positive purchase intentions towards plant-based and cultured meat, we used multinomial linear regressions where purchase intent was entered as the target variable and demographic factors were entered as predictor variables. Factors were considered significant predictors of acceptance where $\mathrm{p}<.05$.

Finally, to identify attitudes and beliefs which were associated with more positive purchase intentions towards plant-based and cultured meat, we used multinomial linear regressions where purchase intent was entered as the target variable and measures of attitudes and beliefs were entered as predictor variables. Factors were considered significant predictors of acceptance where $\mathrm{p}<.05$.

\section{Results \& Discussion}

\subsection{Overall acceptance}

Our first set of analyses simply reports on overall rates of acceptance of plant-based and cultured meat in Brazil. The purpose was to establish the proportion of Brazilian consumers who would try, buy, and pay more for cultured and plant-based meat. The proportion of each sample answering these questions is shown in Figures 3 and 4 for cultured and plant-based meat respectively.

Figure 3: Overall acceptance of cultured meat.

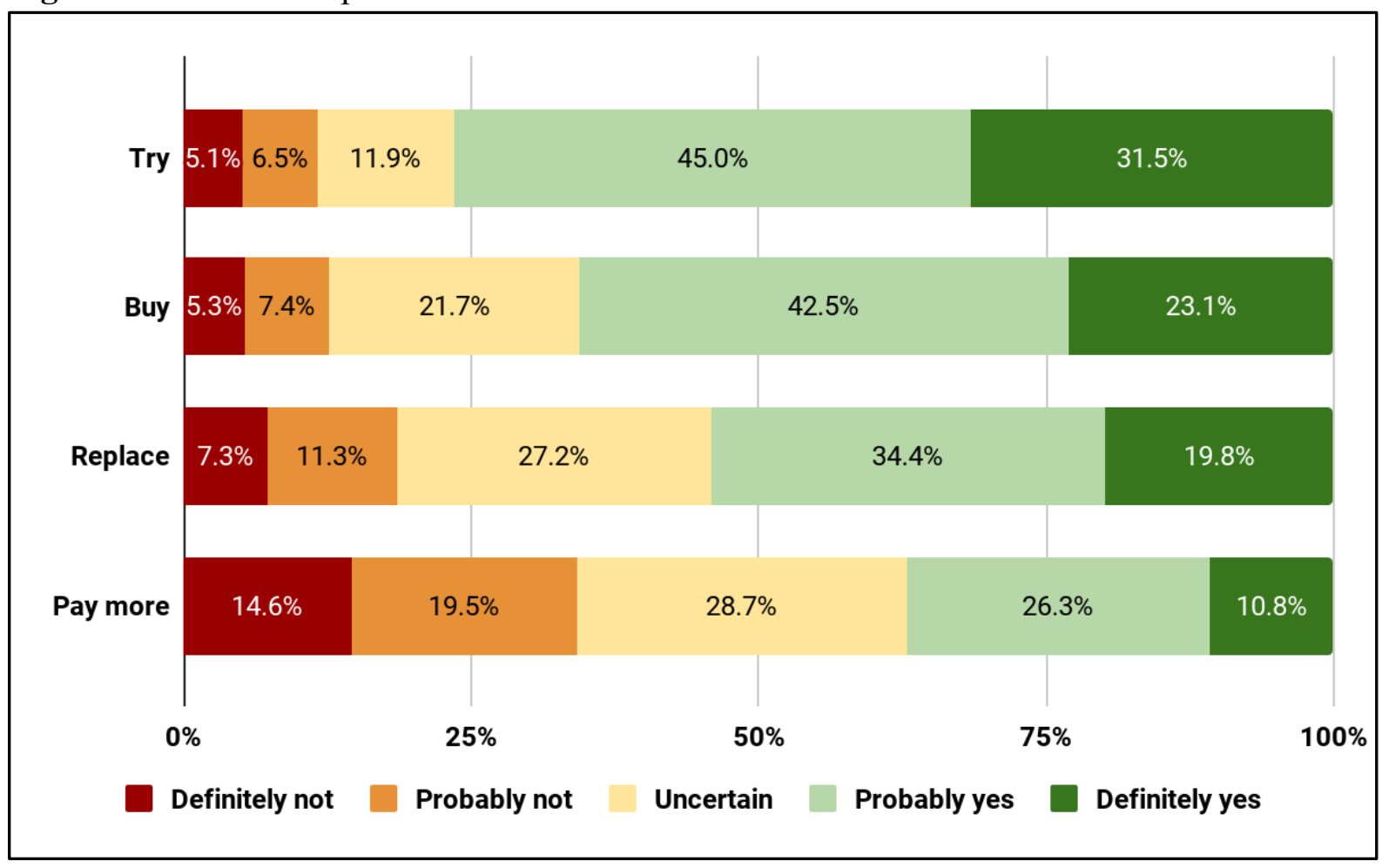


Figure 4: Overall acceptance of plant-based meat.

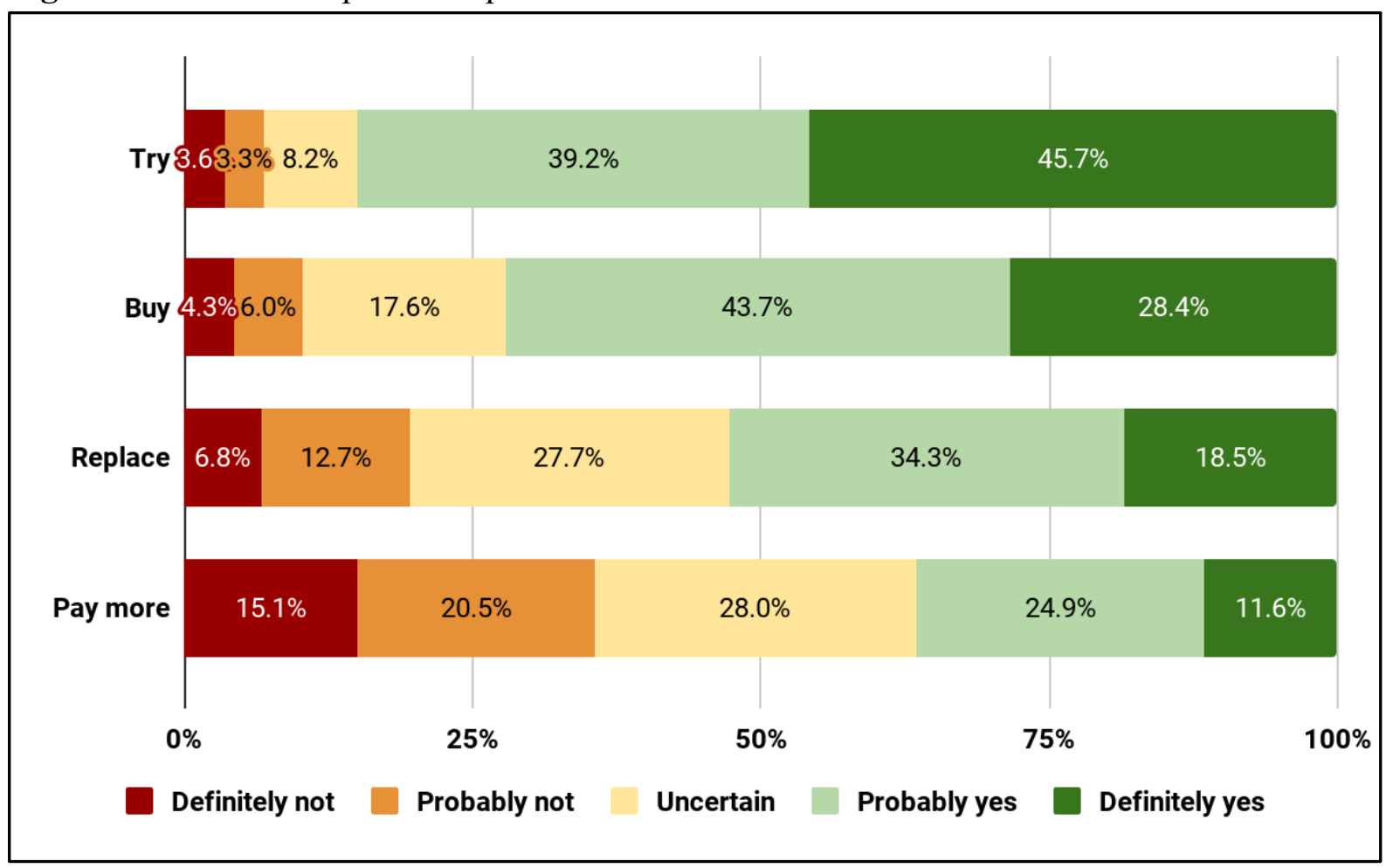

As shown in Figure 3, over three quarters of respondents indicated that they would probably or definitely try cultured meat $(76.5 \%)$, while almost two thirds $(65.6 \%)$ would buy it, more than half $(54.2 \%)$ would use it to replace conventional meat, and over a third $(37.1 \%)$ would pay more.

Some figures for plant-based meat were even more positive, as shown in Figure 4. For that product type, $84.9 \%$ said they would probably or definitely try it, $72.1 \%$ would buy it, $52.8 \%$ would use it to replace conventional meat, and $36.5 \%$ would pay more than for conventional meat.

It is interesting to note that a higher proportion of consumers said they would try or buy plant-based meat compared to those who said they would try or buy cultured meat, but when answering about willingness to replace conventional meat or pay more, the reverse was true. This could indicate that plant-based meat has a broader appeal in that more people are willing to consume it, but cultured meat is more likely to be valued higher than conventional meat. Another factor is that the first technologies of plant-based meat are already available in the market, which may bring more familiarity to the respondents.

The attitudinal measures with respect to cultured and plant-based meat are represented in Figure 5. 
Figure 5: Attitudes towards cultured and plant-based meat on a variety of measures.

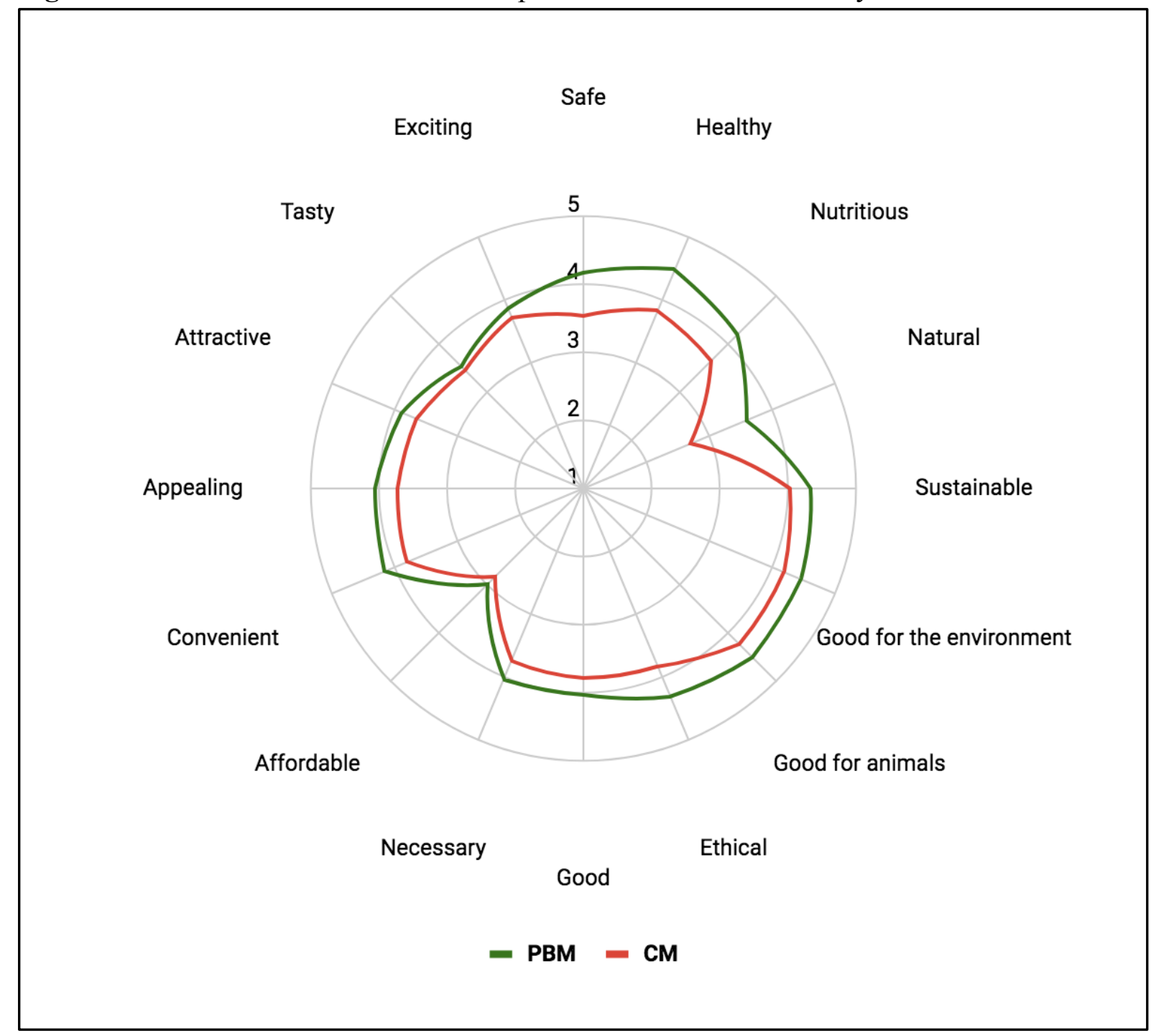

As shown in Figure 5, plant-based meat tended to be perceived more positively than cultured meat across all measures. Differences were particularly pronounced on measures of perceived safety, healthiness, nutrition, and naturalness. While both products were generally perceived positively on measures of ethical and environmental benefits, there seemed to be significantly less positive perceptions in terms of naturalness and affordability. Perceived tastiness was also slightly lower than other measures. The importance of these attitudes in driving purchase intent is analysed in section 3.4.

\subsection{Effect of different names}

Our second set of analyses compared acceptance ratings across the different names tested. The purpose was to identify which names led to highest acceptance of cultured and plantbased meat, and identify differences in the names' descriptiveness and ability to differentiate the product. Differences between the different names for cultured meat are shown in Table 1.

Table 1: Difference in measures of interest between different names for cultured meat. 


\begin{tabular}{|l|c|c|c|c|l|}
\hline Measure & $\begin{array}{c}\text { Carne } \\
\text { cultivada }\end{array}$ & $\begin{array}{c}\text { Carne de } \\
\text { base } \\
\text { celular }\end{array}$ & $\begin{array}{c}\text { Carne } \\
\text { limpa }\end{array}$ & $\begin{array}{c}\text { Carne sem } \\
\text { abate }\end{array}$ & ANOVA \\
\hline Purchase intent* & $\begin{array}{c}3.64^{\mathrm{ab}} \\
(1.139)\end{array}$ & $\begin{array}{c}3.62^{\mathrm{a}} \\
(1.073)\end{array}$ & $\begin{array}{c}3.89^{\mathrm{b}} \\
(0.911)\end{array}$ & $\begin{array}{c}3.67^{\mathrm{ab}} \\
(1.113)\end{array}$ & $\begin{array}{l}\mathrm{F}(3,979)=3.331 \\
\mathrm{p}=0.019\end{array}$ \\
\hline $\begin{array}{l}\text { Name } \\
\text { descriptiveness* }\end{array}$ & $\begin{array}{c}3.93^{\mathrm{a}} \\
(1.073)\end{array}$ & $\begin{array}{c}3.81^{\mathrm{a}} \\
(1.113)\end{array}$ & $\begin{array}{c}3.53^{\mathrm{b}} \\
(1.226)\end{array}$ & $\begin{array}{c}3.97^{\mathrm{a}} \\
(1.144)\end{array}$ & $\begin{array}{l}\mathrm{F}(3,979)=7.551 \\
\mathrm{p}<0.001\end{array}$ \\
\hline $\begin{array}{l}\text { Differentiating } \\
\text { from conventional } \\
\text { meat* }\end{array}$ & $\begin{array}{c}4.06^{\mathrm{a}} \\
(1.107)\end{array}$ & $\begin{array}{c}3.92^{\mathrm{a}} \\
(1.179)\end{array}$ & $\begin{array}{c}3.43^{\mathrm{b}} \\
(1.343)\end{array}$ & $\begin{array}{c}4.10^{\mathrm{a}} \\
(1.096)\end{array}$ & $\begin{array}{l}\mathrm{F}(3,979)=16.71 \\
5, \mathrm{p}<0.001\end{array}$ \\
\hline $\begin{array}{l}\text { Differentiating } \\
\text { from plant-based } \\
\text { meat* }\end{array}$ & $\begin{array}{c}3.71^{\mathrm{a}} \\
(1.212)\end{array}$ & $\begin{array}{c}3.75^{\mathrm{a}} \\
(1.236)\end{array}$ & $\begin{array}{c}3.38^{\mathrm{b}} \\
(1.297)\end{array}$ & $\begin{array}{c}3.59^{\mathrm{ab}} \\
(1.317)\end{array}$ & $\begin{array}{l}\mathrm{F}(3,979)=4.332 \\
\mathrm{p}=0.005\end{array}$ \\
\hline
\end{tabular}

$*$ indicates that the difference between conditions was significant at $p=.05$.

As shown, there were significant differences between the names for cultured meat tested on all of the outcome measures of interest. The name carne limpa ('clean meat') resulted in the strongest purchase intent, and was significantly stronger than the name carne de base celular, from which other names were no different. However, the name carne limpa also performed more poorly on the other three measures of interest, receiving ratings of descriptiveness and ability to differentiate from other types of meat which were significantly worse than the ratings of other names tested.

The differences between the different names tested for plant-based meat are shown below. Unfortunately, due to a programming error, the plant-based meat survey did not ask respondents whether the given name differentiated it from cultured meat (instead asking, nonsensically, whether it differentiated it from plant-based meat). However, differences in the other three measures are shown in Table 2.

Table 2: Difference in measures of interest between different names for plant-based meat.

\begin{tabular}{|l|c|c|c|l|}
\hline Measure & $\begin{array}{c}\text { Carne feita de } \\
\text { plantas }\end{array}$ & Carne vegana & Carne vegetal & ANOVA \\
\hline Purchase intent & $\begin{array}{c}3.88 \\
(1.016)\end{array}$ & $\begin{array}{c}3.82 \\
(1.059)\end{array}$ & $\begin{array}{c}3.88 \\
(1.021)\end{array}$ & $\begin{array}{l}\mathrm{F}(2,866)=0.350, \\
\mathrm{p}=0.705\end{array}$ \\
\hline $\begin{array}{l}\text { Name } \\
\text { descriptiveness }\end{array}$ & $\begin{array}{c}4.12 \\
(1.038)\end{array}$ & $\begin{array}{c}4.08 \\
(1.123)\end{array}$ & $\begin{array}{c}4.20 \\
(1.068)\end{array}$ & $\begin{array}{l}\mathrm{F}(2,866)=0.961, \\
\mathrm{p}=0.383\end{array}$ \\
\hline $\begin{array}{l}\text { Differentiating from } \\
\text { conventional meat* }\end{array}$ & $\begin{array}{c}4.55^{\mathrm{a}} \\
(0.849)\end{array}$ & $\begin{array}{c}4.32^{\mathrm{b}} \\
(0.985)\end{array}$ & $\begin{array}{c}4.47^{\mathrm{ab}} \\
(0.872)\end{array}$ & $\begin{array}{l}\mathrm{F}(2,866)=4.996, \\
\mathrm{p}=0.007\end{array}$ \\
\hline
\end{tabular}

* indicates that the difference between conditions was significant at $p=.05$. 
As shown, carne vegana generally scored poorly compared to the other two names, although this difference was only significant with respect to the ability to differentiate it from conventional meat, on which carne feita de plantas scored most positively.

Overall, these analyses appear to support the name carne cultivada or carne sem abate for cultured meat, and the name carne feita de plantas or carne vegetal for plant-based meat. Previous analogous decisions have seen 'slaughter-free meat' deliberately avoided in English-speaking countries (Szejda \& Urbanovich, 2019), and it seems that there is a benefit to using carne cultivada for consistency with other countries' popular term now being cultured or cultivated meat.

\subsection{Promising consumer profiles}

Our third set of analyses aimed to identify demographic factors which predicted purchase intent of cultured and plant-based meat. The purpose was to identify consumer profiles who may be particularly positive about either product. To this end, we ran two regressions (one for cultured meat and one for plant-based meat). The demographic regressions included purchase intent of the relevant product as the target variable and tested seven predictors based on demographic factors: gender, age, diet, political orientation, level of education, household income, and urbanness. Table 3 shows the demographic regressions for cultured and plantbased meat.

Table 3: Regressions showing the effect of different demographic variables on purchase intent for cultured and plant-based meat.

\begin{tabular}{|l|r|r|l|r|r|}
\hline \multicolumn{5}{|c|}{ Cultured Meat } & \multicolumn{3}{c|}{$\mathrm{F}(7,861)=9.442, \mathrm{p}<0.001$} \\
\hline \multicolumn{2}{|c|}{$\mathrm{F}(7,975)=8.360, \mathrm{p}<0.001$} \\
$\mathrm{R}^{2}=0.057$, Adj $\mathrm{R}^{2}=0.050$ & \multicolumn{2}{c|}{$\mathrm{R}^{2}=0.071$, Adj $\mathrm{R}^{2}=0.064$} \\
\hline Factor & Std. $\boldsymbol{\beta}$ & $\boldsymbol{p}$ & Factor & Std. $\boldsymbol{\beta}$ & $\boldsymbol{p}$ \\
\hline (Constant) & & 0 & Constant & & 0 \\
\hline Gender* & -0.076 & 0.019 & Gender* & 0.068 & 0.044 \\
\hline Age* & -0.098 & 0.003 & Age & 0.047 & 0.173 \\
\hline Diet & 0.027 & 0.385 & Diet* & 0.227 & $<0.001$ \\
\hline Political views & -0.005 & 0.881 & Political views & -0.011 & 0.752 \\
\hline Education* & 0.112 & 0.002 & Education & 0.027 & 0.468 \\
\hline Income* & 0.132 & $<0.001$ & Income & 0.051 & 0.188 \\
\hline Urbanness & 0.036 & 0.262 & Urbanness & 0.042 & 0.228 \\
\hline
\end{tabular}

$*$ indicates that the variable was a significant predictor of purchase intent at $p=.05$.

These regressions reveal some market sectors which are particularly promising for either product type. First, with respect to gender, we see significant effects in opposite directions for 
cultured and plant-based meat. For cultured meat, purchase intent was significantly higher amongst men compared to women, whilst for plant-based meat the reverse was true. This is in line with trends observed in previous research for both products (Aiking, 2011; Bryant \& Barnett, 2020; de Boer et al., 2014).

We also see significantly higher acceptance of cultured meat amongst younger ages, those with higher levels of education, and those with higher levels of income. These relationships to age and level of education are well-established in other literature (Bryant \& Barnett, 2020; Bryant \& Dillard, 2019; Gomez-Luciano et al., 2019; Weinrich, Strack \& Neugebauer, 2020). However, it is rare to observe such a strong correlation to income level. This appears to be linked to some other previous findings about Brazilians' concern about the potential high cost of cultured meat. Gomez-Luciano et al. (2019) found that perceived cost predicted cultured meat acceptance in Brazil, whilst Valente et al. (2019) found that their Brazilian sample were also highly concerned with the cost of food.

With respect to plant-based meat, we see significantly higher purchase intent amongst vegetarians and vegans compared to those following more meat-based diets. This is unsurprising, as presumably vegetarians in Brazil may already be consuming plant-based meat products. Moreover, this is in line with Slade (2018) and van Loo, Caputo and Lusk (2020) who both observed a greater preference for plant-based meat was associated with vegetarianism. This indicates that these products need to consider how to broaden their appeal to also sell to meat-eaters in Brazil. The observation that a vegetarian diet predicted acceptance of plant-based but not cultured meat gives further weight to the argument that cultured meat is uniquely placed to displace demand from heavier meat-eaters and those more attached to meat (Bryant \& Barnett, 2020).

\subsection{Key driving attitudes}

Our fourth set of analyses aimed to identify key attitudes driving purchase intent for cultured and plant-based meat. The purpose was to identify which beliefs about cultured and plantbased meat most strongly predicted purchase intent, thereby identifying important beliefs to affect.

The belief-based regressions included purchase intent of the relevant product as the target variable, and tested 16 predictor variables based on Likert scales with the following labels (15): 'Unhealthy - healthy; Artificial - natural; Bad for the environment-good for the environment; Unethical - ethical; Unappealing - appealing; Not tasty - tasty; Dangerous safe; Expensive - affordable; Bad for animals - good for animals; Unsustainable sustainable; Inconvenient - convenient; Boring - exciting; Not nutritious - nutritious; Unnecessary - necessary; Bad-good; Disgusting - appealing.' Table 4 shows the beliefbased regressions for cultured and plant-based meat. 
Table 4: Regressions showing the effect of different beliefs on purchase intent towards cultured and plant-based meat.

\begin{tabular}{|c|c|c|c|c|c|}
\hline \multicolumn{3}{|c|}{ Cultured Meat } & \multicolumn{3}{|c|}{ Plant-Based Meat } \\
\hline \multicolumn{3}{|c|}{$\begin{array}{c}\mathrm{F}(16,966)=44.110, \mathrm{p}<0.001 \\
\mathrm{R}^{2}=0.422, \text { Adj } \mathrm{R}^{2}=0.413\end{array}$} & \multicolumn{3}{|c|}{$\begin{array}{c}\mathrm{F}(16,852)=34.144, \mathrm{p}<0.001 \\
\mathrm{R}^{2}=0.391, \text { Adj } \mathrm{R}^{2}=0.379\end{array}$} \\
\hline Belief & Std. $\beta$ & $p$ & Belief & Std. $\beta$ & $p$ \\
\hline Constant & & 0 & Constant & & 0 \\
\hline Unhealthy - healthy* & 0.215 & $<0.001$ & Unhealthy - healthy & 0.069 & 0.061 \\
\hline Artificial - natural & 0.056 & 0.065 & Artificial - natural & 0.045 & 0.172 \\
\hline $\begin{array}{l}\text { Bad for the environment - } \\
\text { good for the environment }\end{array}$ & -0.03 & 0.449 & $\begin{array}{l}\text { Bad for the environment - } \\
\text { good for the environment }\end{array}$ & 0.029 & 0.491 \\
\hline Unethical - ethical & -0.007 & 0.857 & Unethical - ethical & -0.043 & 0.302 \\
\hline $\begin{array}{l}\text { Unappealing - } \\
\text { appealing* }\end{array}$ & 0.201 & $<0.001$ & $\begin{array}{l}\text { Unappealing - } \\
\text { appealing* }\end{array}$ & 0.154 & 0.001 \\
\hline Not tasty - tasty & 0.038 & 0.301 & Not tasty - tasty* & 0.196 & $<0.001$ \\
\hline Dangerous - safe & -0.056 & 0.147 & Dangerous - safe & -0.035 & 0.382 \\
\hline Expensive - affordable & -0.014 & 0.616 & Expensive - affordable & -0.021 & 0.487 \\
\hline $\begin{array}{l}\text { Bad for animals - good for } \\
\text { animals }\end{array}$ & 0.001 & 0.971 & $\begin{array}{l}\text { Bad for animals - good for } \\
\text { animals }\end{array}$ & 0.04 & 0.297 \\
\hline $\begin{array}{l}\text { Unsustainable - } \\
\text { sustainable }\end{array}$ & -0.028 & 0.485 & $\begin{array}{l}\text { Unsustainable - } \\
\text { sustainable }\end{array}$ & -0.025 & 0.538 \\
\hline Inconvenient - convenient & 0.084 & 0.055 & Inconvenient - convenient & 0.033 & 0.461 \\
\hline Boring - exciting & 0.082 & 0.052 & Boring - exciting & 0.043 & 0.298 \\
\hline $\begin{array}{l}\text { Not nutritious - } \\
\text { nutritious* }\end{array}$ & -0.111 & 0.008 & Not nutritious - nutritious & -0.043 & 0.282 \\
\hline $\begin{array}{l}\text { Unnecessary - } \\
\text { necessary* }\end{array}$ & 0.145 & 0.002 & Unnecessary - necessary* & 0.091 & 0.033 \\
\hline Bad - good & 0.073 & 0.156 & Bad - good* & 0.195 & $<0.001$ \\
\hline Disgusting - appealing* & 0.109 & 0.021 & Disgusting - appealing & 0.039 & 0.366 \\
\hline
\end{tabular}

* indicates that the variable was a significant predictor of purchase intent at $p=.05$.

Both belief-based regression models accounted well for the variance in purchase intent; the cultured meat regression model predicted $41.3 \%$ of the variance in purchase intent, while the plant-based meat regression model predicted $37.9 \%$ of the variance in purchase intent. Some belief variables were significant predictors of purchase intent for both products: in particular, respondents' ratings of how appealing and how necessary the products were predicted purchase intent in both cases. However, other beliefs predicted purchase intent for one product, but not the other. For cultured meat, significant predictors of purchase intent included perceived healthiness, nutrition, and disgust. For plant-based meat, significant predictors of purchase intent included perceived tastiness and the generic 'bad - good' scale. 
These results indicate that cultured and plant-based meat face unique marketing challenges in Brazil. Those promoting cultured meat will want to focus on its healthiness and nutritional completeness, while avoiding frames such as laboratories which might invoke disgust. On the other hand, those promoting plant-based meat should focus on its tastiness and similarity to conventional meat, since these factors most affected purchase intent for this product.

\section{Conclusions}

This study aimed to learn more about the market for cultured and plant-based meat in Brazil. In particular, we sought to establish the overall rates of acceptance for both, test which names were most appropriate, identify consumer characteristics associated with higher purchase intent, and identify key beliefs and attitudes which drove purchase intent. Our analysis demonstrated some valuable lessons for promoters of plant-based and cultured meat.

\subsection{Cultured meat}

1. There is high overall acceptance of cultured meat in Brazil: $76.5 \%$ would try and $65.6 \%$ would buy cultured meat.

2. The name carne limpa ('clean meat') corresponded to higher purchase intent than other names, but was rated as less descriptive and less differentiating than other names. There were few differences between other names, though carne cultivada and carne sem abate were slightly preferred to carne de base celular. Overall, the name carne cultivada is recommended for strategic and consistency purposes.

3. Cultured meat purchase intent was higher amongst men, younger people, more educated people, and those with higher levels of income.

4. Cultured meat purchase intent was most strongly predicted by perceived appeal, healthiness, nutrition, necessity, and disgust. Promoters should focus on the health and nutritional benefits of cultured meat.

\subsection{Plant based meat}

1. There is high overall acceptance of plant-based meat in Brazil: $84.9 \%$ would try and $72.1 \%$ would buy plant-based meat.

2. The name carne vegana ('vegan meat') scored poorly compared to other names, particularly with respect to the ability to differentiate it from conventional meat. There were few differences between the names carne feita de plantas and carne vegetal. Either name would be appropriate.

3. Plant-based meat purchase intent was higher amongst women and those following vegetarian diets.

4. Plant-based meat purchase intent was most strongly predicted by perceived appeal, taste, necessity, and goodness. Promoters should focus on improving and selling sensory aspects like taste and texture. 


\section{References}

Aiking, H. (2011). Future protein supply. Trends in Food Science \& Technology, 22(2-3), 112-120.

Anderson, J., \& Tyler, L. (2018). Attitudes Toward Farmed Animals in the BRIC Countries. Faunalytics. Available at https://osf.io/preprints/pzuxh/

Brown, L. R. (2009). Growing demand for soybeans threatens Amazon rainforest. Earth Policy Institute.

Bryant, C. J. (2019). A Guide to Effective Animal Campaigning. The Vegan Society. Available at https://www.vegansociety.com/aboutus/research/research-news/project-updateguide-effective-animal-campaigning

Bryant, C., \& Barnett, J. (2020). Consumer Acceptance of Cultured Meat: An Updated Review (2018-2020). Applied Sciences, 10(15), 5201.

Bryant, C., \& Dillard, C. (2019). The impact of framing on acceptance of cultured meat. Frontiers in Nutrition, 6, 103.

Cohen, J. (1992). A power primer. Psychological bulletin, 112(1), 155.

Crimarco, A., Springfield, S., Petlura, C., Streaty, T., Cunanan, K., Lee, J., ... \& Sonnenburg, E. D. (2020). A randomized crossover trial on the effect of plant-based compared with animal-based meat on trimethylamine-N-oxide and cardiovascular disease risk factors in generally healthy adults: Study With Appetizing Plantfood-Meat Eating Alternative Trial (SWAP-MEAT). The American Journal of Clinical Nutrition.

de Boer, J., Schösler, H., \& Aiking, H. (2014). "Meatless days" or "less but better"? Exploring strategies to adapt Western meat consumption to health and sustainability challenges. Appetite, 76, 120-128.

Food Frontier. (2020). Plant-Based Meat: A Healthier Choice? Available at https://www.foodfrontier.org/reports/

Gómez-Luciano, C. A., de Aguiar, L. K., Vriesekoop, F., \& Urbano, B. (2019). Consumers' willingness to purchase three alternatives to meat proteins in the United Kingdom, Spain, Brazil and the Dominican Republic. Food quality and preference, 78, 103732.

OECD-FAO. (2020). OECD-FAO Agricultural Outlook 2020-2029. OECD Publishing, Paris/FAO, Rome. https://doi.org/10.1787/1112c23b-en 
Pereira, E. J. D. A. L., de Santana Ribeiro, L. C., da Silva Freitas, L. F., \& de Barros Pereira, H. B. (2020). Brazilian policy and agribusiness damage the Amazon rainforest. Land Use Policy, 92, 104491.

Slade, P. (2018). If you build it, will they eat it? Consumer preferences for plant-based and cultured meat burgers. Appetite, 125, 428-437.

Szejda, K., and Urbanovich, T. (2019). Meat cultivation: Embracing the science of nature. Project Report. Washington, DC: The Good Food Institute. Available at https://www.gfi.org/files/GFI-Draft-Meat-Cultivation-Report-v8.pdf

The Good Food Institute and Snapcart. (2018). Consumer Research: Plant based market Brazil. The Good Food Institute. Available at https://www.gfi.org/images/uploads/2018/11/GFI plant based market brazil.pdf

Valente, J. D. P. S., Fiedler, R. A., Sucha Heidemann, M., \& Molento, C. F. M. (2019). First glimpse on attitudes of highly educated consumers towards cell-based meat and related issues in Brazil. PloS one, 14(8), e0221129.

Van Loo, E. J., Caputo, V., \& Lusk, J. L. (2020). Consumer preferences for farm-raised meat, lab-grown meat, and plant-based meat alternatives: Does information or brand matter?. Food Policy, 95, 101931.

Weinrich, R., Strack, M., \& Neugebauer, F. (2020). Consumer acceptance of cultured meat in Germany. Meat science, 162, 107924. 